\title{
Pengaruh Motivasi dan Disiplin Kerja Terhadap Kinerja Pengajar Raudhatul Fikri Palembang
}

\author{
SUKARIA DARMAWAN \\ Dosen Tetap Fakultas Ekonomi Universitas Palembang
}

\begin{abstract}
ABSTRAK
Raudhatul inah Fikri Palembang. Hal ini dapat dilihat dari hasil analisis statistik :

a. Koefisien Diterminan $\left(\mathrm{R}^{2}\right)$

Pada hasil $\mathrm{R}$ square $\left(\mathrm{R}^{2}\right)$ didapat nilai sebesar 0,641 artinya persentase sumbangan motivasi dan disiplin kerja terhadap kinerja sebesar 64,1\%, sedangkan sisanya sebesar 35,9\% dipengaruhi oleh variabel lain yang tidak dimasukkan dalam model ini.

b. Uji T (secara parsial)

Pada variabel motivasi $\left(\mathrm{X}_{1}\right)$ diperoleh nilai $\mathrm{t}_{\text {hitung }}$ sebesar 2,393 sedangkan niali $\mathrm{t}_{\text {tabel }}$ sebesar 2,042 , karena $t_{\text {hitung }}(2,393)>\mathrm{t}$ tabel $(2,042)$, berdasarkan uji hipotesis, bahwa motivasi berpengaruh terhadap kinerja.

Pada variabel disiplin kerja $\left(\mathrm{x}_{2}\right)$ di peroleh nilai $\mathrm{t}$ hitung sebesar 3,775 sedangkan nilai $t_{\text {tabel }}$ Sebesar 2,042, karena $t$ hitung $(3,775)>t_{\text {tabel }}(2,042)$, berdasarkan uji hipotesis, maka disiplin kerja secara parsial berpengaruh terhdap kinerja.
\end{abstract}

\section{Kata Kunci : Motivasi, Disiplin dan Kinerja}

\section{A. PENDAHULUAN}

\section{Latar Belakang}

Pendidikan adalah modal dasar untuk menciptakan Sumber Daya Manusia yang unggul.Dunia pendidikan yang utama adalah sekolah.Sekolah merupakan salahsatu lembaga pelayanan pendidikan. Di dunia pendidikan guru memegang posisiyang sangat strategis dalam upaya menciptakan lulusan yang profesional dan berkualitas sehingga dapatm emenuhi kebutuhan sumber daya manusia yang profesional.Kinerja guru di sekolah mempunyai peran yang sangat penting untuk memotivasi dan disiplinnya siswa siswi, guru-guru atau tenaga pengajar guna pencapaian tujuan sekolah.Dengan kita menegakkan disiplin budayanya makaakan dirasakan oleh siswa atau orang tua siswa.Untuk itu guru harus benar-benar kompeten dan konsekuen agar bisa menjalankan tugas sesui dengan peraturanperaturan .

Motivasi bermanfaat untuk meningkatkan kinerja (performace) bawahannya karena dapat berpengaruh dari diri sendiri, orang-orang disekitar kita, pimpinan ditempat kita bekerja dari motivasi, kemampuan, dan lingkungannya. Secara teori berbagai definisi tentang motivasi biasanya terkandung keinginan, harapan, kebutuhan, tujuan, sasaran, dorongan dan insentif. Dengan adanya motivasi seorang pegawai akan merasa adanya dorongan untuk melaksanakan pekerjaan dengan baik, pemenuhan kebutuhan dari para pengajar akan layanan dan penghargaanoleh atasan terhadap prestasi kerja yang dihasilkannya yang sesuai dengan prinsip keadlilan dapat memotivasi kerja mereka, namun jika kurangnya motivasi terhadap para bawahan maka para pegawai kurang semangat dalam melaksankan tugas-tugasnya. Seperti di Raudhatul Aminah Fikri kurangnya semangat kerja dikarenakan gaji yang diperoleh tidak berdasarkan UMR dan kurangnya kompensasi ataupun insentif 
yang diberikan.

Selain itu, kinerja guru juga ditentukan oleh disiplin kerja yang tinggi.Dengan demikian sekolah yang didalam proses belajar-mengajar tumbuh kedisiplinan, akan berfungsi sebagai pembentuk nilai dan norma individu, penguasaan diri, sikap dan tanggung jawab bagi guru.Kurang disiplinnya guru-guru dalam melaksanakan tugas,seperti datang kesekolah terlambat akan berakibat kualitas peserta didik menja direndah.

Sedangkan menurut Moenir ( 2016 : 152 ) mengatakan bahwa disiplin adalah ketaatan yang sikapnya impersonal, tidak memakai perasan dan tidak memakai perhitungan pamrih atau kepentingan pribadi.

Kinerja merupakan suatu fungsi dari motivasi dan kemampuan. Untuk menyelesaikan tugas atau pekerjaan seseorang patutnya memiliki derajat kesediaan dan tingkat kemampuan tertentu. Kinerja merupakan perilaku nyata yang ditampilkan setiap orang sebagai prestasi kerja yang dihasilkan oleh karyawan sesuai dengan perannya dalam perusahaan. Kinerja merupakan suatu hal yang sangat penting dalam upaya perusahaan mencapai tujuan.

Melihat fenomena diatas masih banyak para tenaga pengajar di Raudhatul Fikri Palembang yang terlambat dan sering izin, maka penuliti tertarik untuk melakukan penelitian dengan judul " Pengaruh Motivasi dan Disiplin Kerja Terhadap Kinerja Pengajar Raudhatul Fikri Palembang".

\subsection{Perumusan Masalah}

Berdasarkan latar belakang yang telah dikemukakan di atas maka dapat dirumuskan masalah penelitian ini adalah :

1. Apakah motivasi berpengaruh terhadap kinerja para pengajar Raudhatul Fikri Palembang.
2. Apakah disiplin kerja berpengaruh terhadap kinerja pengajar Raudhatul Fikri Palembang.

3. Apakah motivasi dan disiplin kerja berpengaruh secara simultan terhadap kinerja pengajar Raudhatul Fikri Palembang.

\subsection{Tujuan Penelitian}

1. Tujuan dari peneliti adalah untuk mengetahui pengaruh motivasi terhadap kinerja para pengajar Raudhatul Fikri Palembang.

2. Tujuan dari peneliti adalah untuk mengetahui pengaruh disiplin kerja terhadap kinerja pengajar Raudhatul Fikri Palembang.

3. Tujan dari peneliti adalah untuk mengetahui apakah motivasi dan disiplin kerja berpengaruh secara simultan terhadap kinerja pengajar Raudhatul Fikri Palembang.

\section{B. LANDASAN TEORI}

\section{Pengertian Motivasi}

Motivasi ialah keinginan untuk berbuat sesuatu, sedangkan motif adalah kebutuhan,keinginan,dorongan. Motivasi merupakan keinginan yang terdapat pada seseorang individu yang merangsangnya untuk melakukan tindakan-tindakan atau sesuatu yang menjadi dasar atau alasan seseorang berprilaku. Motivasi kerja dapat diartikan sebagai keinginan atau kebutuhan yang melatarbelakangi seseorang sehingga ia terdorong untuk bekerja. Motivasi dapat berasal dari dalam diri maupun luar diri seseorang.

Menurut Usman ( 20014:250 ) mengatakan bahwa :Motivasikerja dapat diartika sebagai keinginan atau kebutuhan yang melatarbelakangi seseorang sehingga ia terdorong untuk bekerja.

Selanjutnya menurut Hasibuan ( 2016 : 95 ) motivasi adalah pemberian daya 
penggerak yang menciptakan kegairahan kerja seseorang, agar mereka mau bekerja sama, bekerja efektif dan terintegrasi dengan segala daya upayanya untuk mencapai kepuasan.

Sedangkan menurut Siagian (2002:102) menjelaskan bahwa motivasi adalah daya pendorong yang mengakibatkan seorang anggota organisasi mau dan rela untuk mengerahkan kemampuan dalam bentuk keterampilan dan keahlian, tenaga dan waktu untuk menyelenggaran berbagai kegiatan yang menjadi tanggung jawabnya dan menunaikan kewajibannya, dalam rangka pencapaian tujuan dan berbagai sasaran organisasi yang telah ditentukan sebelumnya.

\section{METODE PENELITIAN}

\section{Uji Validitas}

Menurut Situmorang ( $2010: 69$ ), menunjukkan sejauh mana suatu alat pengukur itu mengukur apa yang ingin diukur. Suatu skala pengukur dikatakan valid apabila skala tersebut digunakan untuk mengukur apa yang seharusnya diukur.

1. Jika $r$ hitung $>r$ tabel, maka pertanyaan dinyatakan valid

2. Jika $\mathrm{r}_{\text {hitung }}<\mathrm{r}$ tabel, maka pertanyaan dinyatakan tidak valid

Dalam penelitian ini disebarkan kuisioner sebagai alat pengumpulan data yang berisi pertanyaan yang menyangkut pengaruh motivasi dan disiplin kerja terhadap kinerja pengajar.

\section{Uji Reliabilitas}

Pengujian reliabilitas data dilakukan untuk mengetahui sejauh mana suatu pengukur dapat menunjukkan akurasi dan konsistensi butir pertanyaan. Untuk menguji reliabilitas data digunakan pengukur Cronbach Alpha. Menurut Sugiyono ( 2008 : 458 ) bahwa, "Cronbach Alpha merupakan salah satu koefisien reliabilitas yang paling sering digunakan". Skala pengukuran yang reliabel sebaiknya memiliki nilai Cronbach Alpha minimal 0.60.

\section{Analisi Deskriptif}

Metode penganalisisan data dengan cara bmenyusun data, mengelompokannya selanjutnya menginterprestasikannya sehingga diperoleh gambaran sebenarnya mengenai kondisi yang akan diteliti.

\subsubsection{Regresi Berganda}

Untuk mengetahiu pengaruh atau hubungan variabel bebas dan variabel tidak bebas dengan menggunakan metode regresi berganda ( Multiply Regressio ).

Rumusnya adalah sebagai berikut :

$$
\mathbf{Y}=\mathbf{a}+\mathbf{b}_{1} \mathbf{x}_{1}+\mathbf{b}_{2} \mathbf{x}_{2}+\mathbf{e}
$$

Dimanna :

$$
\begin{array}{ll}
\mathrm{Y} & =\text { Kinerja } \\
\mathrm{a} & =\text { Konstanta } \\
\mathrm{b}_{1} \mathrm{~b}_{2}=\text { Koefisien regresi } & =\text { Motivasi } \\
\mathrm{X}_{1}=\text { Disiplin } \\
\mathrm{X}_{2} \quad=\text { Standar Error } \\
\mathrm{e}
\end{array}
$$

\section{PEMBAHASAN}

1. Variabel Motivasi.

a. Atasan selalu memberikan semangat kepada pengajar.

\begin{tabular}{|l|c|c|}
\hline \multirow{2}{*}{ Pernyataan } & \multicolumn{2}{|c|}{$\begin{array}{c}\text { Pengajar dan } \\
\text { Pegawai }\end{array}$} \\
\cline { 2 - 3 } & Frekuensi & \% \\
\hline Sangat Setuju & 15 & 50 \\
Setuju & 13 & 43.3 \\
Kurang Setuju & 2 & 6.7 \\
Tidak Setuju & 0 & 0 \\
Sangat Tidak & 0 & 0 \\
Setuju & & \\
\hline \multicolumn{1}{|c|}{ Jumlah } & $\mathbf{3 0}$ & $\mathbf{1 0 0}$ \\
\hline
\end{tabular}

Sumber : Data diolah, 2014 
Hasil responden bagaimana seorang atasan selalu memberikan semangat kepada tenaga pengajar adalah sebanyak 15 responden atau sebesar 50\% menyatakan sangat setuju, 13 responden atau sebesar 43,3\% menyatakan setuju dan 2responden atau sebesar $6,7 \%$ menyatakan kurang setuju. Ini memperlihatkan bahwa variabel atasan selalu memberikan semangat kepada pengajar berdampak positif terhadap kinerja pengajar.

b. Setiap hasil pekerjaan selalu memberikan motivasi tersendiri bagi saya

\begin{tabular}{|c|c|c|}
\hline \multirow[t]{2}{*}{ Pernyataan } & \multicolumn{2}{|c|}{$\begin{array}{c}\text { Pegawai dan } \\
\text { pengajar }\end{array}$} \\
\hline & Frekuensi & $\%$ \\
\hline Sangat Setuju & 9 & 30 \\
\hline Setuju & 18 & 60 \\
\hline Kurang Setuju & 3 & 10 \\
\hline Tidak Setuju & 0 & 0 \\
\hline $\begin{array}{l}\text { Sangat } \\
\text { Setuju }\end{array}$ & 0 & 0 \\
\hline Jumlah & 30 & 100 \\
\hline
\end{tabular}

Hasil responden tentang bagaimana setiap hasil pekerjaan selalu memberikan motivasi tersendiri bagi saya adalah sebanyak 9 responden atau sebesar 30\% menyatakan sangat setuju, 18 responden atau sebesar $60 \%$ menyatakan setuju dan 3 responden atau sebesar $10 \%$ menyatakan kurang setuju. Ini memperlihatkan bahwa variabel setiap hasil pekerjaan selalu memberikan motivasi tersendiri bagi saya berdampak positif bagi kinerja pengajar.

c. Saat bekerja saya fokus untuk memperoleh hasil yang terbaik

\begin{tabular}{|l|c|c|}
\hline \multirow{2}{*}{ Pernyataan } & \multicolumn{2}{|c|}{$\begin{array}{c}\text { Pengawai dan } \\
\text { Pengajar }\end{array}$} \\
\cline { 2 - 3 } & Frekuensi & $\%$ \\
\hline Sangat Setuju & 18 & 60 \\
Setuju & 11 & 36.7 \\
\hline
\end{tabular}

\begin{tabular}{|l|c|c|}
\hline Kurang & 1 & 3.3 \\
Setuju & 0 & 0 \\
Tidak Setujju & 0 & 0 \\
Sangat Tidak & & \\
Setuju & & \\
\hline \multicolumn{1}{|c|}{ Jumlah } & $\mathbf{3 0}$ & $\mathbf{1 0 0}$ \\
\hline
\end{tabular}

Hasil responden tentang bagaimana saat bekerja saya fokus untuk memperoleh hasil yang baik adalah 18 responden atau sebesar $60 \%$ menyatakan sangat setuju,11 responden atau sebesar $36,7 \%$ menyatakan setuju dan 1 responden atau sebesar 3,3\% menyatakan kurang setuju. Ini memperlihatkan bahwa variabel saat bekerja saya fokus untuk memperoleh hasil yang baik berdampak positif terhadap kinerja pengajar.

\begin{tabular}{|c|c|c|}
\hline \multirow[t]{2}{*}{ Pernyataan } & \multicolumn{2}{|c|}{$\begin{array}{c}\text { Pengajar dan } \\
\text { pegawai }\end{array}$} \\
\hline & Frekuensi & $\%$ \\
\hline Sangat Setuju & 9 & 30 \\
\hline Setuju & 19 & 63.3 \\
\hline Kurang Setuju & 2 & 6.7 \\
\hline Tidak Setuju & 0 & 0 \\
\hline $\begin{array}{l}\text { Sangat Tidak } \\
\text { Setuju }\end{array}$ & 0 & 0 \\
\hline Jumlah & 30 & 100 \\
\hline
\end{tabular}

Hasil responden tentang bagaimana atasan saya selalu memperhatikan dan selalu memberikan pujian kepada bawahannya apabila pekerjaan diselesaikan dengan baik adalah sebanyak 9 responden atau sebesar $30 \%$ menyatakan sangat setuju, 19 responden atau sebesar 63,3\% menyatakan setuju dan 2 responden atau sebesar 6,7\% menyatakan kurang setuju. Ini memperlihatkan bahwa variabel atasan saya selalu memperhatikan dan selalu 
memberikan pujian kepada bawahannya apabila pekerjaan diselesaikan dengan baik berdampak positif terhadap kinerja pengajar.

\section{b. Pimpinan saya memberikan reward dalam bentuk bonus dan insentif kepada bawahan yang bekerja dengan baik}

\begin{tabular}{|l|c|c|}
\hline \multirow{2}{*}{ Pernyataan } & \multicolumn{2}{|c|}{$\begin{array}{c}\text { Pegawai dan } \\
\text { pengajar }\end{array}$} \\
\cline { 2 - 3 } & Frekuensi & \% \\
\hline Sangat Setuju & 11 & 36,7 \\
Setuju & 15 & 50 \\
Kurang Setuju & 4 & 13.3 \\
Tidak Setuju & 0 & 0 \\
Sangat Tidak & 0 & 0 \\
Setuju & & \\
\hline \multicolumn{1}{|c|}{ Jumlah } & $\mathbf{3 0}$ & $\mathbf{1 0 0}$ \\
\hline
\end{tabular}

Hasil responden tentang bagaimana pimpinan saya memberikan reward dalam bentuk bonus dan insentif kepada bawahan yang bekerja dengan baik adalah sebanyak 11 responden atau sebesar $36,7 \%$ menyatakan sangat setuju, 15 responden atau sebesar $50 \%$ menyatakan setuju dan 4 responden atau sebesar 13,3\% menyatakan kurang setuju. Ini mempelihatkan bahwa Pimpinan saya memberikan reward dalam bentuk bonus dan insentif kepada bawahan yang bekerja dengan baik berdampak positif terhadap kinerja pengajar.

\section{c. Pimpinan saya selalu menilai suatu tugas yang diberikan kepada bawahan}

\begin{tabular}{|l|c|c|}
\hline \multirow{2}{*}{ Pernyataan } & \multicolumn{2}{|c|}{$\begin{array}{c}\text { Pegawai dan } \\
\text { pengajar }\end{array}$} \\
\cline { 2 - 3 } & Frekuensi & \% \\
\hline Sangat Setuju & 11 & 36.7 \\
Setuju & 15 & 50 \\
Kurang Setuju & 4 & 13.3 \\
Tidak Setuju & 0 & 0 \\
Sangat Tidak & 0 & 0 \\
Setuju & & \\
\hline
\end{tabular}

\begin{tabular}{|l|l|l|}
\hline Jumlah & 30 & 100 \\
\hline
\end{tabular}

Hasil responden tentang bagaimana pimpinan saya selalu menilai suatu tugas yang diberikan kepada bawahan adalah sebanyak 11 responden atau sebesar 36,7\% menyatan sangat setuju, 15 responden atau sebesar 30\% menyatakan setuju dan4 responden atau sebesar 13,3\% menyatakan kurang setuju. Ini memperlihatkan bahwa pimpinan saya selalu menilai suatu tugas yang diberikan kepada bawahan berdampak positif bagi kinerja pengajar.

2. Variabel Disiplin Kerja

a. Setiap pekerjaan harus dapat saya pertanggung jawabkan

\begin{tabular}{|l|c|c|}
\hline \multirow{2}{*}{ Pernyataan } & \multicolumn{2}{|c|}{$\begin{array}{c}\text { Pengajar dan } \\
\text { pegawai }\end{array}$} \\
\cline { 2 - 3 } & Frekuensi & $\%$ \\
\hline Sangat Setuju & 6 & 20 \\
Setuju & 11 & 36.7 \\
Kurang & 12 & 40 \\
Setuju & 1 & 3.3 \\
Tidak Setuju & 0 & 0 \\
Sangat Tidak & & \\
Setuju & & $\mathbf{1 0 0}$ \\
\hline \multicolumn{1}{|c|}{ Jumlah } & $\mathbf{3 0}$ & \\
\hline
\end{tabular}

Hasil responden tentang bagaimana Setiap pekerjaan harus dapat saya pertanggung jawabkan adalah sebanyak 6 responden atau sebesar $20 \%$ menyatakan sangat setuju, 11 responden atau sebesar $36,7 \%$ menyatakan setuju dan 1 responden atau sebesar 3,3\% menyatakan kurang setuju. Ini memperlihatkan bahwa variabel setiap pekerjaan dapat saya pertanggung jawabkan berdampak positif bagi kinerja pengajar.

b. Pimpinan saya ikut bertanggung jawab dalam tugas yang dikerjakan oleh bawahannya. 


\begin{tabular}{|l|c|c|}
\hline \multirow{2}{*}{ Pernyataan } & \multicolumn{2}{|c|}{$\begin{array}{c}\text { Pengajar dan } \\
\text { pegawai }\end{array}$} \\
\cline { 2 - 3 } & Frekuensi & \% \\
\hline Sangat Setuju & 7 & 23.3 \\
Setuju & 11 & 36.7 \\
Kurang & 10 & 33.3 \\
Setuju & 2 & 6.7 \\
Tidak Setuju & 0 & 0 \\
Sangat Tidak & & \\
Setuju & & $\mathbf{1 0 0}$ \\
\hline \multicolumn{1}{|c|}{ Jumlah } & $\mathbf{3 0}$ & \\
\hline
\end{tabular}

Hasil responden tentang bagaimana pimpinan saya ikut bertanggung jawab dalam tugas yang dikerjakan oleh bawahannya adalah sebanyak 7 responden atau sebesar $23,3 \%$ menyatakan sangat setuju, sebanyak 11 responden atau sebesar $36,7 \%$ menyatakan setuju, 10 responden atau sebesar 33,3\% menyatakan kurang setuju dan 2 responden atau sebesar 6,7\% menyatakan tidak setuju. Ini memperlihatkan bahwa variabel pimpinan saya ikut bertanggung jawab dalam tugas yang dikerjakan oleh bawahannya berdampak positif bagi kinerja pengajar.

\section{c. Pimpinan saya mengawasi bawahannya saat bekerja}

\begin{tabular}{|l|c|c|}
\hline \multirow{2}{*}{ Pernyataan } & \multicolumn{2}{|c|}{$\begin{array}{c}\text { Pengajar dan } \\
\text { pegawai }\end{array}$} \\
\cline { 2 - 3 } & Frekuensi & \% \\
\hline Sangat Setuju & 14 & 46.7 \\
Setuju & 9 & 30 \\
Kurang & 6 & 20 \\
Setuju & 1 & 3.3 \\
Tidak Setuju & 0 & 0 \\
Sangat Tidak & & \\
Setuju & & $\mathbf{1 0 0}$ \\
\hline \multicolumn{1}{|c|}{ Jumlah } & $\mathbf{3 0}$ & \\
\hline
\end{tabular}

Hasil responden tentang bagaimana pimpinan saya mengawasi bawahannya saat bekerja adalah sebanyak 14 responden atau sebesar $46,7 \%$ menyatakan sangat setuju, sebanyak 9 responden atau sebesar 30\% menyatakan setuju, sebanyak 6 responden atau sebesar 20\% menyatakan kurang setuju, dan sebanyak 1 responden atau sebesar 3,3\% menyatakan sangat tidak setuju. Ini memperlihatkan bahwa variabel pimpinan saya mengawasi bawahaanya saat bekerja berdampak positif terhadap kinerja pegawai.

d. Saya selalu menyelesaikan tugas tepat waktu

\begin{tabular}{|l|c|c|}
\hline \multirow{2}{*}{ Pernyataan } & \multicolumn{2}{|c|}{$\begin{array}{c}\text { Pengajar dan } \\
\text { pegawai }\end{array}$} \\
\cline { 2 - 3 } & Frekuensi & \% \\
\hline Sangat Setuju & 10 & 33.3 \\
Setuju & 11 & 36.7 \\
Kurang Setuju & 8 & 26.7 \\
Tidak Setuju & 1 & 3.3 \\
Sangat Tidak & 0 & 0 \\
Setuju & & $\mathbf{1 0 0}$ \\
\hline \multicolumn{1}{|c|}{ Jumlah } & $\mathbf{3 0}$ & \\
\hline
\end{tabular}

Hasil responden tentang bagaimana Saya selalu menyelesaikan tugas tepat waktu adalah sebanyak 10 responden atau sebesar $33,3 \%$ menyatakan sangat setuju, sebanyak 11 responden atau sebesar 36,7\% menyatakan setuju, sebnayak 8 responden atau sebesar $26,7 \%$ menyatakan kurang setuju dan 1 responden atau sebesar 22,2\% menyatakan tidak setuju. Ini memperlihatkan bahwa variabel saya selalu menyelesaikan tugas tepat waktu berdampak positif bagi kinerja pengajar.

\section{e. Pemimpin dan para pengajar lainnya} datang lebih dulu dari pada saya

\begin{tabular}{|l|c|c|}
\hline \multirow{2}{*}{ Pernyataan } & \multicolumn{2}{|c|}{ Pengajar dan pegawai } \\
\cline { 2 - 3 } & Frekuensi & \% \\
\hline Sangat Setuju & 14 & 46.7 \\
Setuju & 11 & 36.7 \\
Kurang & 4 & 13.3 \\
Setuju & 1 & 3.3 \\
Tidak Setuju & 0 & 0 \\
Sangat Tidak & & \\
Setuju & & \\
\hline
\end{tabular}




\section{Jumlah}

30

Hasil responden tentang bagaimana pimpinan dan para tenaga pengajar lain datang lebih dulu dari pada saya adalah sebanyak 14 responden atau sebesar 46,7\% menyatakan sangat setuju, sebanyak 11 responden atau sebesar 36,7\% menyatakan setuju, sebanyak 4 responden atau sebesar $13,3 \%$ menyatakan kurang setuju, dan 1 responden atau sebanyak 33,3\% menyatakan tidak setuju. Ini memperlihatkan bahwa variabel pimpinan dan para tenaga pengajar lain datang lebih dulu dari pada saya berdampak positif bagi kinerja pengajar.

\section{f. Peraturan yang dibuat oleh pimpinan dan yayasan selalu berjalan sesuai dengan prosedur yang berlaku}

\begin{tabular}{|l|c|c|}
\hline \multirow{2}{*}{ Pernyataan } & \multicolumn{2}{|c|}{$\begin{array}{c}\text { Pengajar dan } \\
\text { pegawai }\end{array}$} \\
\cline { 2 - 3 } & Frekuensi & \% \\
\hline Sangat Setuju & 14 & 46.7 \\
Setuju & 11 & 36.7 \\
Kurang Setuju & 4 & 13.3 \\
Tidak Setuju & 1 & 3.3 \\
Sangat Tidak & 0 & 0 \\
Setuju & & \\
\hline \multicolumn{1}{|c|}{ Jumlah } & $\mathbf{3 0}$ & $\mathbf{1 0 0}$ \\
\hline
\end{tabular}

Hasil responden tentang peraturan yang dibuat oleh pimpinan dan yayasan selalu berjalan sesuai dengan prosedur yang berlaku adalah sebanyak 14 responden atau sebesar 46,7\% menyatakan sangat setuju, sebanyak 11 responden atau 36,7\% menyatakan setuju, sebanyak 4 responden atau 13,3\% menyatakan kurang setuju, dan sebanyak 1 responden atau sebesar 3.3\% menyatakan tidak setuju. Ini memperlihatkan bahwa variabel peraturan yang dibuat oleh pimpinan dan yayasan selalu berjalan sesuai dengan prosedur yang berlaku berdampak positif bagi kinerja pengajar.

\section{Variabel Kinerja}

a. Dalam menyelesaikan tugas saya jarang melakukan kesalahan

\begin{tabular}{|l|c|c|}
\hline \multirow{2}{*}{ Pernyataan } & \multicolumn{2}{c|}{$\begin{array}{c}\text { Pengajar dan } \\
\text { pegawai }\end{array}$} \\
\cline { 2 - 3 } & Frekuensi & \% \\
\hline Sangat Setuju & 12 & 40 \\
Setuju & 16 & 53.3 \\
Kurang Setuju & 2 & 6.7 \\
Tidak Setuju & 0 & 0 \\
Sangat Tidak & 0 & 0 \\
Setuju & & \\
\hline \multicolumn{1}{|c|}{ Jumlah } & $\mathbf{3 0}$ & $\mathbf{1 0 0}$ \\
\hline
\end{tabular}

Hasil responden tentang bagaimana dalam menyelesaikan tugas saya jarang melakukan kesalahan adalah sebanyak 12 responden atau sebanyak $40 \%$ menyatakn sangat setuju, sebanyak 16 responden atau sebesar 53,3\% menyatakan setuju, dan sebanyak 2 responden atau $6,7 \%$ menyatakan kurang setuju. Ini memperlihatkan bahwa variabel dalam menyelesaikan tugas saya jarang melakukan kesalahan berdampak positif terhadap kinerja pengajar.

b. Saya selalu tepat waktu dalam menyelesaikan pekerjaan yang diberikan

\begin{tabular}{|l|c|c|}
\hline \multirow{2}{*}{\multicolumn{1}{|c|}{ Pernyataan }} & \multicolumn{2}{c|}{$\begin{array}{c}\text { Pengajar dan } \\
\text { pegawai }\end{array}$} \\
\cline { 2 - 3 } & Frekuensi & \% \\
\hline Sangat Setuju & 14 & 46.7 \\
Setuju & 11 & 36.7 \\
Kurang Setuju & 5 & 16.7 \\
Tidak Setuju & 0 & 0 \\
Sangat Tidak Setuju & 0 & 0 \\
\hline \multicolumn{1}{|c|}{ Jumlah } & $\mathbf{3 0}$ & $\mathbf{1 0 0}$ \\
\hline
\end{tabular}

Hasil responden tentang bagaimana saya selalu tepat waktu dalam menyelesaikan pekerjaan yang diberikan 
adalah sebanyak 14 responden atau sebesar $46,7 \%$ menyatakan sangat setuju, 11 responden atau sebesar $36,7 \%$ menyatakan setuju dan sebanyak 5 responden dan sebesar $16,7 \%$ menyatakan kurang setuju. Ini memperlihatkan bahwa variabel saya selalu tepat waktu dalam menyelesaikan pekerjaan yang diberikan berdampak positif terhadap kinerja pengajar.

\section{c. Saya tidak ragu untuk meminta bantuan atau petunjuk dari pimpinan/pengajar lain untuk melakukan pekerjaan.}

\begin{tabular}{|l|c|c|}
\hline \multirow{2}{*}{\multicolumn{1}{|c|}{ Pernyataan }} & \multicolumn{2}{c|}{$\begin{array}{c}\text { Pengajar dan } \\
\text { pegawai }\end{array}$} \\
\cline { 2 - 3 } & Frekuensi & \% \\
\hline Sangat Setuju & 12 & 40 \\
Setuju & 14 & 46.7 \\
Kurang Setuju & 4 & 13.4 \\
Tidak Setuju & 0 & 0 \\
Sangat Tidak Setuju & 0 & 0 \\
\hline \multicolumn{1}{|c|}{ Jumlah } & $\mathbf{3 0}$ & $\mathbf{1 0 0}$ \\
\hline
\end{tabular}

Hasil responden tentang bagaimana saya tidak ragu untuk meminta bantuan atau petunjuk dari pimpinan/pengajar lain untuk melakukan pekerjaan adalah sebanyak 12 responden atau sebesar $40 \%$ menyatakan sangat setuju, dan sisanya sebanyak 14 responden atau sebesar 46,7\% menyatakan setuju dan 4 responden atau sebesar 13,4\% meyatakan kurang setuju. Ini memperlihatkan bahwa variabel saya tidak ragu untuk memintak bantuan atau petunjuk dari pimpinan/pengajar lain untuk melakukan pekerjaan berdampak positif terhadap kinerja pengajar.

\section{d. Pimpinan saya senantiasa memberikan petunjuk kepada pengajar dalam mengerjakan tugas- tugasnya.}

\begin{tabular}{|l|c|c|}
\hline \multirow{2}{*}{\multicolumn{1}{|c|}{ Pernyataan }} & \multicolumn{2}{c|}{$\begin{array}{c}\text { Pengajar dan } \\
\text { pegawai }\end{array}$} \\
\cline { 2 - 3 } & Frekuensi & $\mathbf{\%}$ \\
\hline Sangat Setuju & 4 & 13.3 \\
Setuju & 19 & 20 \\
Kurang Setuju & 6 & 63.3 \\
Tidak Setuju & 1 & 3.3 \\
Sangat Tidak Setuju & 0 & 0 \\
\hline \multicolumn{1}{|c|}{ Jumlah } & $\mathbf{3 0}$ & $\mathbf{1 0 0}$ \\
\hline
\end{tabular}

Hasil responden tentang bagaimana pimpinan saya senantiasa memberikan petunjuk kepada pengajar dalam mengerjakan tugas-tugasnya adalah sebanyak 4 responden atau sebesar 13,3\% menyatakan sangat setuju, 19 responden atau sebesar $20 \%$ menyatakan setuju, sebanyak 6 responden atau sebesar $63,3 \%$ menyatakan kurang setuju, 1 responden atau sebesar 3,3\% menyatakan tidak setuju. Ini memperlihatkan bshwa variabel pimpinan saya senantiasa memberikan perunjuk kepada pengjar dalam mengerjakan tuigastugasnya berdampak positif bagi kinerja pengajar.

\section{e. Saya dapat bekerja sama dengan baik antara pimpinan dan tenaga pengajar lainnya dan selalu bermusyawarah/rapat pada saat ada acara tertentu yang akan di adakan.}

\begin{tabular}{|l|c|c|}
\hline \multirow{2}{*}{\multicolumn{1}{|c|}{ Pernyataan }} & \multicolumn{2}{c|}{$\begin{array}{c}\text { Pengajar dan } \\
\text { pegawai }\end{array}$} \\
\cline { 2 - 3 } & Frekuensi & \% \\
\hline Sangat Setuju & 6 & 20 \\
Setuju & 20 & 66.7 \\
Kurang Setuju & 4 & 13 \\
Tidak Setuju & 0 & 0 \\
Sangat Tidak Setuju & 0 & 0 \\
\hline \multicolumn{1}{|c|}{ Jumlah } & $\mathbf{3 0}$ & $\mathbf{1 0 0}$ \\
\hline
\end{tabular}

Hasil responden tentang Saya dapat bekerja sama dengan baik antara pimpinan 
dan tenaga pengajar lainnya dan selalu bermusyawarah/rapat pada saat ada acaran tertentu yang akan di adakan adalah sebanyak 6 responden atau 20\% menyatakan sangat setuju, 20 responden atau sebesar $66,7 \%$ menyatakan setuju dan sebnayak 4 rsponden atau 13,4\% menyatakan kurang setuju. Ini memperlihatkan bahwa variabel Saya dapat bekerja sama dengan baik antara pimpinan dan tenaga pengajar lainnya dan selalu bermusyawarah/rapat pada saat ada acara tertentu yang akan diadakan berdampak positif bagi kinerja pengajar.

\section{f. Adanya kesesuaian antara tugas dan tanggung jawab yang dilakukan pengajar}

\begin{tabular}{|l|c|c|}
\hline \multirow{2}{*}{\multicolumn{1}{|c|}{ Pernyataan }} & \multicolumn{2}{c|}{ Pengajar dan pegawai } \\
\cline { 2 - 3 } & Frekuensi & \% \\
\hline Sangat Setuju & 6 & 20 \\
Setuju & 20 & 66.7 \\
Kurang Setuju & 4 & 20 \\
Tidak Setuju & 0 & 0 \\
Sangat Tidak Setuju & 0 & 0 \\
\hline \multicolumn{1}{|c|}{ Jumlah } & $\mathbf{3 0}$ & $\mathbf{1 0 0}$ \\
\hline
\end{tabular}

Hasil responden tentang bagaimana adanya kesesuaian antara tugas dan tanggung jawab yang dilakukan pengajar adalah sebanyak 6 responden atau sebesar $20 \%$ menyatakan sangat setuju, sebanyak 20 responden atau sebesar $66,7 \%$ menyatakan satuju, dan sebanyak 4 responden atau sebesar 20\% menyatakan kurang setuju. Ini memperlihatkan bahwa variabel adanya kesesuaian antara tugas dan tanggung jawab yang dilakukan pengajar berdampak positif terhadap kinerja pengajar.

\section{HASIL PEMBAHASAN}

Persamaan regresi yang menggambarkan dan menjelaskan pengaruh dua variabel bebas terhadap variabel terikat, dimana hubungan ke tiganya dapat digambarkan sebagai suatu garis lurus, untuk melihat variabel karakteristik terhadap kinerja pengajar maka peneliti menggunakan model regresi berganda sebagai berikut adalah :

$$
\mathbf{Y}=\mathbf{a}+\mathbf{b}_{1} \mathbf{x}_{1}+\mathbf{b}_{2} \mathbf{x}_{2}+\mathbf{e}
$$

Dimana :

$\mathrm{Y} \quad=$ Kinerja

a $\quad=$ Konstanta

$\mathrm{b}_{1}, \mathrm{~b}_{2}=$ Koefisien regresi

$\mathrm{X}_{1}=$ Motivasi

$\mathrm{X}_{2} \quad=$ Disiplin

e $\quad=$ Standar Error

Perhitungan ini menggunakan regresi berganda dengan mempergunakan SPSS. Dimana variabel $\mathrm{X}_{1}$ adalah motivasi dan variabel $\mathrm{X}_{2}$ adalah disiplin yang mempengaruhi variabel $\mathrm{Y}$ adalah kinerja. 
Tabel 4.1

Tabel Rekapitulasi Data Jawaban Kuesioner Motivasi, Disiplin Kerja dan Kinerja

\begin{tabular}{|c|c|c|c|c|c|c|c|c|c|c|c|c|c|c|c|c|c|c|c|c|c|}
\hline \multirow[b]{2}{*}{ No } & \multicolumn{6}{|c|}{ Motivasi } & \multirow[b]{2}{*}{$\mathbf{X}_{1}$} & \multicolumn{6}{|c|}{ Disiplin } & \multirow[b]{2}{*}{$\mathrm{X} 2$} & \multicolumn{6}{|c|}{ Kinerja } & \multirow[b]{2}{*}{ Y } \\
\hline & 1 & 2 & 3 & 4 & 5 & & & 1 & 2 & 3 & 4 & 5 & & & 1 & 2 & 3 & 4 & 5 & 6 & \\
\hline 1 & 4 & 4 & & 1 & 2 & & 25 & & 4 & & & & & 23 & 3 & 4 & 3 & 2 & 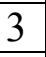 & & 18 \\
\hline 2 & 4 & & & & & & & & & & & & & 6 & & & $t$ & & 5 & & 27 \\
\hline 3 & 4 & 4 & & 4 & 4 & & & & & & & & & 4 & 4 & 4 & 4 & & 4 & & 24 \\
\hline 4 & & & & 7 & & & 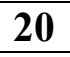 & & & & & & & 0 & & 4 & $t$ & & - & & 24 \\
\hline 5 & & & & & & & & & & & & & & - & & & $t$ & & & & 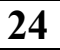 \\
\hline 6 & & 5 & & 2 & & & & & & & & & & & & & & & & & 24 \\
\hline 7 & & & & & & & & & & & & & & 0 & & & 4 & & & & 21 \\
\hline 8 & 5 & 4 & & 4 & & & & & & & & & & 5 & & & 4 & & & & 24 \\
\hline 9 & - & & & & & & 9 & & & & & & & 20 & & & 3 & + & 4 & & 25 \\
\hline 10 & & & & & & & & & & & & & & 4 & & & $t$ & & & & 24 \\
\hline 11 & 4 & 4 & & 2 & & & 24 & & 3 & & & & & 25 & & & 5 & & 4 & 4 & 25 \\
\hline 12 & & & & & & & & & & & & & & 4 & & & $t$ & & & + & 24 \\
\hline 13 & & & & & & & & & & & & & & & & & & & & & 28 \\
\hline 14 & & 4 & & 2 & & & 25 & & 4 & & & & & 8 & & & 5 & & & & 27 \\
\hline 15 & & 5 & & 5 & & & 30 & & 4 & & & & & & & & & & & & 30 \\
\hline 16 & & 4 & & 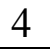 & & & 24 & & & & & & & & & & & & & & 22 \\
\hline 17 & 2 & 4 & & 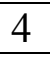 & 2 & & 24 & & 3 & & & & 4 & 21 & & & 3 & & 4 & 4 & 22 \\
\hline 18 & & 5 & & 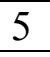 & & & & & 5 & & & & & 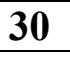 & & & 5 & & & & 30 \\
\hline 19 & & 4 & & 2 & & & 28 & & & & & & & 26 & & & 5 & & & & 27 \\
\hline 2 & - & 5 & & 5 & 5 & & & & J & & & & & & & & & & & & 26 \\
\hline 21 & 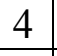 & 4 & & 5 & & & & & & & & & & 20 & & & 5 & & & & 27 \\
\hline 22 & 4 & 4 & 4 & 4 & & - & 22 & & 3 & & 3 & & & 18 & 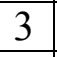 & 4 & 4 & 4 & 3 & 3 & 21 \\
\hline 23 & 4 & 4 & 7 & 4 & - & & & & & & & & & & & & 4 & & & & 24 \\
\hline 24 & 5 & 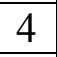 & 5 & 4 & 4 & - & 26 & & 4 & & 4 & & 4 & 24 & 1 & 5 & 4 & 4 & 4 & 4 & 25 \\
\hline 25 & 5 & 5 & & - & 5 & & & & $T$ & & & & $\therefore$ & $\angle 0$ & - & - & $\mathrm{J}$ & 4 & 4 & 4 & 27 \\
\hline 26 & 5 & 5 & 5 & 5 & & 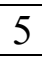 & & & 5 & & & & & 28 & 5 & & -1 & 5 & & & 30 \\
\hline 27 & 5 & 5 & 5 & 4 & 5 & 5 & 2 & & 5 & 5 & & 5 & 5 & & $-{ }_{1}$ & 5 & 5 & 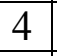 & 4 & 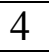 & 27 \\
\hline 28 & 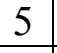 & 3 & 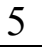 & - & 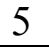 & 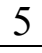 & 20 & & 3 & 3 & 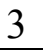 & 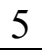 & 3 & 28 & 5 & 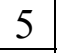 & 5 & 5 & 4 & 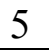 & 29 \\
\hline 29 & 4 & 4 & 5 & 3 & 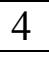 & $T$ & 24 & & 3 & 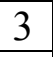 & 8 & 3 & . & 18 & 4 & 3 & 4 & 3 & 4 & 4 & 22 \\
\hline 30 & $T$ & 4 & & 5 & 4 & & 26 & 2 & 2 & $z$ & 2 & 2 & 2 & 12 & 4 & 3 & 4 & 3 & 4 & 4 & 22 \\
\hline
\end{tabular}

Dari hasil perhitungan sekor pernyataan kuesioner motivasi, disiplin kerja dan kinerja maka didapat hasil perhitungan regresi berganda sebagai berikut : 


\section{Uji Validasi}

\begin{tabular}{|c|c|c|}
\multicolumn{2}{|c}{ Hasil Uji Validitas Motivasi $\left(\mathbf{X}_{\mathbf{1}}\right)$} \\
\hline Butir Pertanyaan & $\begin{array}{c}\text { Corrected Item Total } \\
\text { Correlation }\end{array}$ & Status \\
\hline Butir 1 & 0,725 & Valid \\
\hline Butir 2 & 0,661 & Valid \\
\hline Butir 3 & 0,587 & Valid \\
\hline Butir 4 & 0,411 & Valid \\
\hline Butir 5 & 0,913 & Valid \\
\hline Butir 6 & 0,913 & Valid \\
\hline
\end{tabular}

Item-Total Statistik

\begin{tabular}{|c|c|c|c|c|}
\hline & $\begin{array}{c}\text { Scale Mean if } \\
\text { Item Deleted }\end{array}$ & $\begin{array}{c}\text { Scale Variance } \\
\text { if Item } \\
\text { Deleted }\end{array}$ & $\begin{array}{c}\text { Orrected } \\
\text { Item-Total } \\
\text { Correlation }\end{array}$ & $\begin{array}{c}\text { Cronbach's } \\
\text { Alpha if Item } \\
\text { Deleted }\end{array}$ \\
\hline Motivasi 1.1 & 21,4667 & 6,257 & 0,725 & 0,862 \\
Motivasi 1.2 & 21,7000 & 6,493 & 0,661 & 0,873 \\
Motivasi 1.3 & 21,3333 & 6,851 & 0,587 & 0,883 \\
Motivasi 1.4 & 21,6667 & 7,333 & 0,411 & 0,908 \\
Motivasi 1.5 & 21,6667 & 5,540 & 0,913 & 0,828 \\
Motivasi 1.6 & 21,6667 & 5,540 & 0,913 & 0,828 \\
\hline
\end{tabular}

Hasil olah data SPSS 20

Hasil Uji Validitas Disiplin Kerja $\left(\mathrm{X}_{2}\right)$

\begin{tabular}{|c|c|c|}
\hline Butir Pertanyaan & $\begin{array}{c}\text { Corrected Item Total } \\
\text { Correlation }\end{array}$ & Status \\
\hline Butir 1 & 0,443 & Valid \\
\hline Butir 2 & 0,716 & Valid \\
\hline Butir 3 & 0,853 & Valid \\
\hline Butir 4 & 0,707 & Valid \\
\hline Butir 5 & 0,830 & Valid \\
\hline Butir 6 & 0,830 & Valid \\
\hline
\end{tabular}

Item-Total Statistik

\begin{tabular}{|c|c|c|c|c|}
\hline & $\begin{array}{c}\text { Scale Mean if } \\
\text { Item Deleted }\end{array}$ & $\begin{array}{c}\text { Scale Variance } \\
\text { if Item } \\
\text { Deleted }\end{array}$ & $\begin{array}{c}\text { Orrected } \\
\text { Item-Total } \\
\text { Correlation }\end{array}$ & $\begin{array}{c}\text { Cronbach's } \\
\text { Alpha if Item } \\
\text { Deleted }\end{array}$ \\
\hline Motivasi 1.1 & 20,5000 & 14,121 & 0,443 & 0,921 \\
Motivasi 1.2 & 20,4667 & 12,257 & 0,716 & 0,883 \\
Motivasi 1.3 & 20,0333 & 11,620 & 0,853 & 0,861 \\
Motivasi 1.4 & 20,2333 & 12,461 & 0,707 & 0,884 \\
Motivasi 1.5 & 19,9667 & 12,202 & 0,830 & 0,866 \\
Motivasi 1.6 & 19,9667 & 12,202 & 0,830 & 0,866 \\
\hline
\end{tabular}

Hasil olah data SPSS 20 
Hasil Uji Validitas Kinerja (Y)

\begin{tabular}{|c|c|c|}
\hline Butir Pertanyaan & $\begin{array}{c}\text { Corrected Item Total } \\
\text { Correlation }\end{array}$ & Status \\
\hline Butir 1 & 0,731 & Valid \\
\hline Butir 2 & 0,563 & Valid \\
\hline Butir 3 & 0,734 & Valid \\
\hline Butir 4 & 0,535 & Valid \\
\hline Butir 5 & 0,677 & Valid \\
\hline Butir 6 & 0,677 & Valid \\
\hline
\end{tabular}

Item-Total Statistik

\begin{tabular}{|c|c|c|c|c|}
\hline & $\begin{array}{c}\text { Scale Mean if } \\
\text { Item Deleted }\end{array}$ & $\begin{array}{c}\text { Scale Variance } \\
\text { if Item } \\
\text { Deleted }\end{array}$ & $\begin{array}{c}\text { Orrected } \\
\text { Item-Total } \\
\text { Correlation }\end{array}$ & $\begin{array}{c}\text { Cronbach's } \\
\text { Alpha if Item } \\
\text { Deleted }\end{array}$ \\
\hline Motivasi 1.1 & 20,5667 & 6,323 & 0,731 & 0,818 \\
Motivasi 1.2 & 20,6000 & 6,248 & 0,563 & 0,852 \\
Motivasi 1.3 & 20,6333 & 5,964 & 0,734 & 0,815 \\
Motivasi 1.4 & 21,0333 & 6,585 & 0,535 & 0,854 \\
Motivasi 1.5 & 20,8333 & 6,557 & 0,677 & 0,828 \\
Motivasi 1.6 & 20,8333 & 6,557 & 0,677 & 0,828 \\
\hline
\end{tabular}

Hasil olah data SPSS 20

\section{Uji Reliabilitas}

\begin{tabular}{|l|c|c|}
\hline \multicolumn{2}{|c}{ Hasil Uji Reliabilitas } \\
\hline Variabel & $\begin{array}{c}\text { Alpha } \\
\text { Cronbach } \\
(\mathbf{a})\end{array}$ & status \\
\hline Motivasi & 0,886 & Reliabel \\
\hline $\begin{array}{l}\text { Displin } \\
\text { Kerja }\end{array}$ & 0,899 & Reliabel \\
\hline Kinerja & 0,857 & Reliabel \\
\hline
\end{tabular}

b. Reliabilitas Disiplin Kerja

Reliability statistic

\begin{tabular}{|c|c|}
\hline $\begin{array}{c}\text { Cronbach's } \\
\text { Alpha }\end{array}$ & N of Items \\
\hline 0,899 & 6 \\
\hline
\end{tabular}

c. Reliabilitas Kinerja

Reliability statistic

\begin{tabular}{|c|c|}
\hline $\begin{array}{c}\text { Cronbach's } \\
\text { Alpha }\end{array}$ & N of Items \\
\hline 0,857 & 6 \\
\hline
\end{tabular}

\section{a. Reliabilitas Motivasi}

Reliability statistic

\begin{tabular}{|c|c|}
\hline Cronbach's Alpha & N of Items \\
\hline 0,886 & 6 \\
\hline
\end{tabular}

\section{Analisis Deskriptif Statistik}

Model summary

\begin{tabular}{|c|c|c|c|c|}
\hline Model & R & R Square & $\begin{array}{c}\text { Adjusted R } \\
\text { Square }\end{array}$ & $\begin{array}{c}\text { Std. Error of } \\
\text { the Estimate }\end{array}$ \\
\hline 1 & $.800^{\mathrm{a}}$ & .641 & .641 & 1.85580 \\
\hline
\end{tabular}

Predictors : ( Constant ), DISIPLIN, MOTIVASI 
a. $\mathrm{R}$ dalam analisis regresi berganda menunjukan korelasi (korelation pearson), yaitu korelasi antara dua variabel independent. Angka $\mathrm{R}$ didapat 0,800 artinya morelasi variabel dengan kinerja sebesar 0,800. Hal ini berarti terjadi hubungan yang sangat erat karena nilai mendekati 1.

b. $\mathrm{R}$ Square $\left(\mathrm{R}^{2}\right)$ atau kuadrat dari $\mathrm{R}$, yaitu menunjukan nilai koefisien deteminasi. Angka ini akan diubah kebentuk persentase sumbangan pengaruh variabel independent terhadap variabel dependent. Nilai $\mathrm{R}^{2}$ sebesar 0,641 artunya persentase sumbangan motivasi dan disiplin kerja terhadap kinerja sebesar 64,1\%, sedangkan sisanya dipengaruhi oleh variabel lain yang tidak dimasukkan dalam model ini.

c. Adjusted $R$ Square adalah $\mathrm{R}$ Square yang telah disesuaikan, nilai sebesar 0,614 menunjukan sumbangan pengaruh variabel independent terhadap variabel dependent.

d. Standar Error of Estimated ( standar deviasi) adalah ukuran kesalahan prediksi, nilai sebesar 1,85580 artnya kesalahan dalam memperediksi kinerja sebesar 1,85580 .

\section{Analisis Regresi Berganda}

Tabel 4.5

\begin{tabular}{|ll|r|r|r|r|r|}
\hline \multirow{2}{*}{ Model } & \multicolumn{2}{|c|}{$\begin{array}{c}\text { Unstandardized } \\
\text { Coefficients }\end{array}$} & $\begin{array}{c}\text { Standardized } \\
\text { Coefficients }\end{array}$ & \multirow{2}{*}{ T } & \multirow{2}{*}{ Sig. } \\
\cline { 3 - 5 } & \multicolumn{1}{|r|}{ B } & \multicolumn{1}{c|}{ Std. Error } & \multicolumn{2}{c|}{ Beta } & & \\
\hline 1 & ( Constant) & 6.564 & 3.018 & & 2.175 & .039 \\
& MOTIVASI & .345 & .144 & .345 & 2.393 & .024 \\
& DISIPLIN & .388 & .103 & .544 & 3.775 & .001 \\
\hline
\end{tabular}

Dependent Variable : KINERJA

\begin{tabular}{|ll|r|r|r|r|r|}
\hline \multirow{2}{*}{ Model } & \multicolumn{2}{|c|}{$\begin{array}{c}\text { Unstandardized } \\
\text { Coefficients }\end{array}$} & $\begin{array}{c}\text { Standardized } \\
\text { Coefficients }\end{array}$ & \multirow{2}{*}{ T } & \multirow{2}{*}{ Sig. } \\
\cline { 3 - 5 } & \multicolumn{1}{|r|}{ B } & \multicolumn{1}{c|}{ Std. Error } & \multicolumn{1}{c|}{ Beta } & & \\
\hline 1 & ( Constant) & 6.564 & 3.018 & & 2.175 & .039 \\
& MOTIVASI & .345 & .144 & .345 & 2.393 & .024 \\
& DISIPLIN & .388 & .103 & .544 & 3.775 & .001 \\
\hline
\end{tabular}

a.Dependent Variable : KINERJA

a. pengujian variabel motivasi $\left(b_{1}\right)$ dengan hipotesis :

$\mathrm{H}_{0}$ :koefisien regresi ( motivasi) tidak berpengaruh secara parsial terhadap kinerja

$\mathrm{H}_{1}$ : koefisien regresi (motivasi) berpengaruh secara parsial terhadap kinerja.

ANOVA $^{\mathrm{a}}$

\begin{tabular}{|c|c|c|c|c|c|}
\hline Model & $\begin{array}{l}\text { Sum of } \\
\text { Squares }\end{array}$ & Df & Mean Square & $\mathbf{F}$ & Sig. \\
\hline $\begin{array}{ll}1 & \text { Regression } \\
& \text { Residual } \\
& \text { Total }\end{array}$ & $\begin{array}{r}165.712 \\
92.988 \\
258.700\end{array}$ & $\begin{array}{r}2 \\
27 \\
29\end{array}$ & $\begin{array}{r}82.856 \\
3.444\end{array}$ & 24.058 & $.000^{\mathrm{b}}$ \\
\hline
\end{tabular}

a.Dependent Variabel : KINERJA

b.Predictors : ( Constant ), DISIPLIN, MOTIVASI 
$\mathrm{H}_{0}: \mathrm{b}_{1}, \mathrm{~b}_{2}=0$, artinya secara bersama-sama tidak terdapat pengaruh yang positif dan signifikan dari variabel bebas $\left(\mathrm{X}_{1}, \mathrm{X}_{2}\right)$ yaitu berupa motivasi dan disiplin terhadap kinerja pengajar sebagai variabel terikat $(\mathrm{Y})$.

$H_{1}: b_{1}, b_{2} \neq 0$, artinya secara bersama-sama terdapat pengaruh yang positif dan signifikan dari variabel bebas $\left(\mathrm{X}_{1}, \mathrm{X}_{2}\right)$ yaitu berupa motivasi dan disiplin kerjaterhadap kinerja pengajar sebagai variabel terikat (Y).

Berdasarkan hasil output $\mathrm{F}$ hitung diperoleh sebesar 24,058 Untuk mencari $\mathrm{F}$ tebel pada signifikansi 0,05 dengan derajat kebebasan $\mathrm{df}=\mathrm{n}-\mathrm{k}-1$ atau 30-2-1=27 maka diperoleh nilai untuk $F_{\text {tabel }} 3,316$

Jika $\mathrm{F}_{\text {hitung }}<\mathrm{F}$ tabel, maka $\mathrm{H}_{0}$ diterima

Jika $\mathrm{F}_{\text {hitung }}>\mathrm{F}_{\text {tabel, }}$ maka $\mathrm{H}_{1}$ ditolak

Karena $\mathrm{F}$ hitung $(24,058)>\mathrm{F}$ tabel ( 3,316), maka $\mathrm{H}_{0}$ ditolak, $\mathrm{H}_{1}$ diterima, artinya bahwa motivasi dan disiplin kerja secara bersama berpengaruh terhadap kinerja.

\section{KESIMPULAN}

Berdasarkan pengamatan dan analisis terhadap data penelitian yang dilakukan, maka peneliti mengambil kesimpulan sebagai berikut : bahwa motivasi dan displin kerja berpengaruh positif dan signifikan terhadap kinerja pengajar Raudhatul inah Fikri Palembang. Hal ini dapat dilihat dari hasil analisis statistik :

a. Koefisien Diterminan $\left(\mathrm{R}^{2}\right)$

Pada hasil $\mathrm{R}$ square $\left(\mathrm{R}^{2}\right)$ didapat nilai sebesar 0,641 artinya persentase sumbangan motivasi dan disiplin kerja terhadap kinerja sebesar $64,1 \%$, sedangkan sisanya sebesar $35,9 \%$ dipengaruhi oleh variabel lain yang tidak dimasukkan dalam model ini. b. Uji T (secara parsial )

Pada variabel motivasi $\left(\mathrm{X}_{1}\right)$ diperoleh nilai $\mathrm{t}$ hitung sebesar 2,393 sedangkan niali $t_{\text {tabel }}$ sebesar 2,042 , karena $t_{\text {hitung }}($ $2,393)>t$ tabel $(2,042)$, berdasarkan uji hipotesis, bahwa motivasi berpengaruh terhadap kinerja.

- Pada variabel disiplin kerja $\left(\mathrm{x}_{2}\right)$ di peroleh nilai $t$ hitung sebesar 3,775 sedangkan nilai $t_{\text {tabelsebesar }} 2,042$, karena $\mathrm{t}$ hitung $(3,775)>\mathrm{t}_{\text {tabel }}(2,042)$, berdasarkan uji hipotesis, maka disiplin kerja secara parsial berpengaruh terhdap kinerja.

c. Uji F (secara simultan)

Pada pengujian variabel independen ( motivasi, disiplin kerja) secara bersamasama terhadap variabel dependen (kinerja) diperoleh nilai $\mathrm{F}$ hitung sebesar 24,058 sedangkan nilai $\mathrm{F}$ tabel sebesar 3,316 , karena $\mathrm{F}$ hitung $(24,058)>\mathrm{F}$ tabel (3,316), berdasarkan hipotesis, bahwa motivasi dan disiplin kerja secara bersama-sama berpengaruh terhadap kinerja.

\section{DAFTAR PUSTAKA}

Hasibuan, 2016. Organisasi dan Motivasi

Dasar Peningkatan

Produktivitas.Bandung: Bumi Aksara.

Hasibuan, Fandy, 2013. Disiplin kerja.Diambil pada tanggal 21 November 2014 dari http://respository.usu.ac.id/bltstream /123456789/25947/4/chapter.pdf.

Hikman, Usman, 2015.Manajemen, Teori, Praktik, dan Riset Pendidikan.Yogyakarta : Bumi Aksara.

Moenir, 2001. Pendekatan Manusia dan Organisasi Terhadap Pembinaan Kepegawaian.Jakarta : Gunung Agung. 
Muhammad, 2009. Manajemen Sumber Daya Manusia. Diambil pada tanggal 21 November 2014 dari http://respository.usu.ac.id/bltstream /123456789/25947/4/chapter.pdf.

Rivai, 2016. Manajemen Sumber Daya Manusia untuk Perusahaan. Buku edisi 2. Jakarta: Rajawali Pers.

Robert L. Marthis, John H. Jakson, 2011. Pengaruh Kinerja.Diamabil pada tanggal 21 November 2014 dari http://.id.wikipedia.org/wiki/kinerja.

Salim peter, 2014. Manajemen, Teori, Praktik, dan Riset Pendidikan.Yogyakarta : Bumi Aksara.

Siagian, 2013. Filsafat Administrasi.Jakarta : Bumi Aksara.

Singodimejo, 2014. Teori Tentang Lingkungan Kerja.Diambil pada tanggal 21 November 2014 dari http://respository.usu.ac.id/bltstream /123456789/25947/4/chapter.pdf.

Situmorang, 2015. Diambil pada tanggal 21 November 2016 dari http://eprints.uny.ac.id/9579/2/bab207104244063.pdf.

Stroner, Freeman, 2014.Manajemen Teori, Praktik, dan Riset Pendidikan. Buku edisi 3. Yogyakarta: Penerbit Bumi Aksara.

Sugiyono,2014. Metode Penelitian Bisnis.Jakarta: Alfabeta.

Sugiyono, 2015. Metode Penelitian Bisnis.Bandung: Alfabeta.

Sugiyono, 2012. Metode Penelitian Bisnis. Bandung: Alfabeta.

Sutrisno, 2015. Manajemen Sumber Daya Manusia. Jakarta: Kencana.

Timothy. A, 2014. Prilaku Organisasi.Buku 1, Jakarta: Selemba Empat.

Usman, 2015.Manajemen Teori, Praktik, dan Riset Pendidikan.Buku edisi 3. Yogyakarta: Penerbit Bumi Aksara.

http://eprints.uny.ac.id/9579/2/bab2- 07104244063.pdf.
http://jurnalsdm.blogspot.com/2019/07/kine
rja-karyawan-definisi-faktor-yang.html. 